\title{
STUDI KASUS TENTANG PENGEMBANGAN PROSES BISNIS PT SINAR SOSRO
}

\author{
Dino Caesaron dan Andrian
}

Email : dcaesaron@bundamulia.ac.id

\section{Penulis}

Dino Caesaron adalah dosen di Universitas Bunda Mulia dalam bidang Manajemen Operasional (simulasi, antrian dan perancangan fasilitas)

\section{Abstrak}

Penelitian ini merupakan pengembangan dari studi kasus proses bisnis PT Sinar Sosro. Permasalahan yang dialami PT Sinar Sosro dalam memasarkan salah satu produknya Joy Tea Green tidaklah semulus dan sebaik produk pendahulunya Teh Botol. Beberapa latarbelakang permasalahan dirumuskan dengan menggunakan teknik brainstorming diantaranya berupa keterlambatan pengenalan (launch) produk Joy Tea Green, kurang tepatnya segmentasi pasar hingga desain kemasan dan iklan yang terlihat menjemukan. Beberapa rekomendasi dihasilkan agar permasalahan ini dapat diselesaikan diantaranya dengan melakukan re-desain proses bisnis PT Sinar Sosro, dimulai dari segmentasi ulang pasar, diferensiasi produk yang berbeda dengan produk lainnya, hingga proses rancang ulang kemasan yang lebih.

\section{Keywords}

Brainstorming, Proses Bisnis, Segementasi Pasar, Diferensiasi Produk

\section{PENDAHULUAN}

Mengkonsumsi teh adalah bagian tradisi dari orang Asia. Kebiasaan meminum teh ini bukan lagi hanya sekedar tradisi biasa bahkan sudah menjadi budaya, tidak hanya di Asia bahkan seluruh dunia termasuk Eropa. Inggris merupakan salah satu Negara yang mengadopsi budaya minum teh tersebut.Salah satu teh terkenal mereka yaitu: Morning dan Afternoon teh. di Iraq, Orang-orang selalu menyempatkan untuk meminum teh walaupun 
mereka sedang sibuk, juga di India dan banyak Negara lainnya. Jadi, jika kita melihat peluang tentang teh dewasa ini, ini akan menjadi satu peluang bisnis yang sangat baik.

Teh pertama kali di perkenalkan di Indonesia di tahun 1684 dalam bentuk daun teh dari Jepang yang dibawa oleh orang Jerman bernama Andreas Cleyer dan ditanam sebagai tanaman hias di jakarta.Pada 1694, seorang pendeta bernama F. Valentijn melaporkan melihat tanaman teh muda tumbuh di taman istana milik gubernur jendral Champuysdi Jakarta. Pada 1826, tanaman teh berhasil di tanam dan di tambahkan menjadi koleksiTaman Botani Bogor, dan pada 1827, juga berhasil di tanam di Taman Eksperimen Cisurupan (Garut, Jawa Barat). Kesuksesan dalam skala besar di Wanayasa (Purwakarta) and Raung (Banyuwangi) membukakan jalan kepada Jacobus Isidorus Loudewijk Levian Jacobson, seorang ahli teh, untuk mendirikan lembaga bisnis teh di Jawa. Pada 1828, selama masa pemerintahan gubernur Van Den Bosch, teh merupakan salah satu tanaman yang dipaksa untuk di tanam pada masa tanam paksa.Teh merupakan tanaman yang banyak memiliki kegunaan. Tangkai atau batang nya dapat digunaka sebagai bahan kerjainan tangan, sedangkan daunnya di konsumsi setelah diproses menjadi berbagai macam teh, yang ditunjukkan grafik dibawah ini.

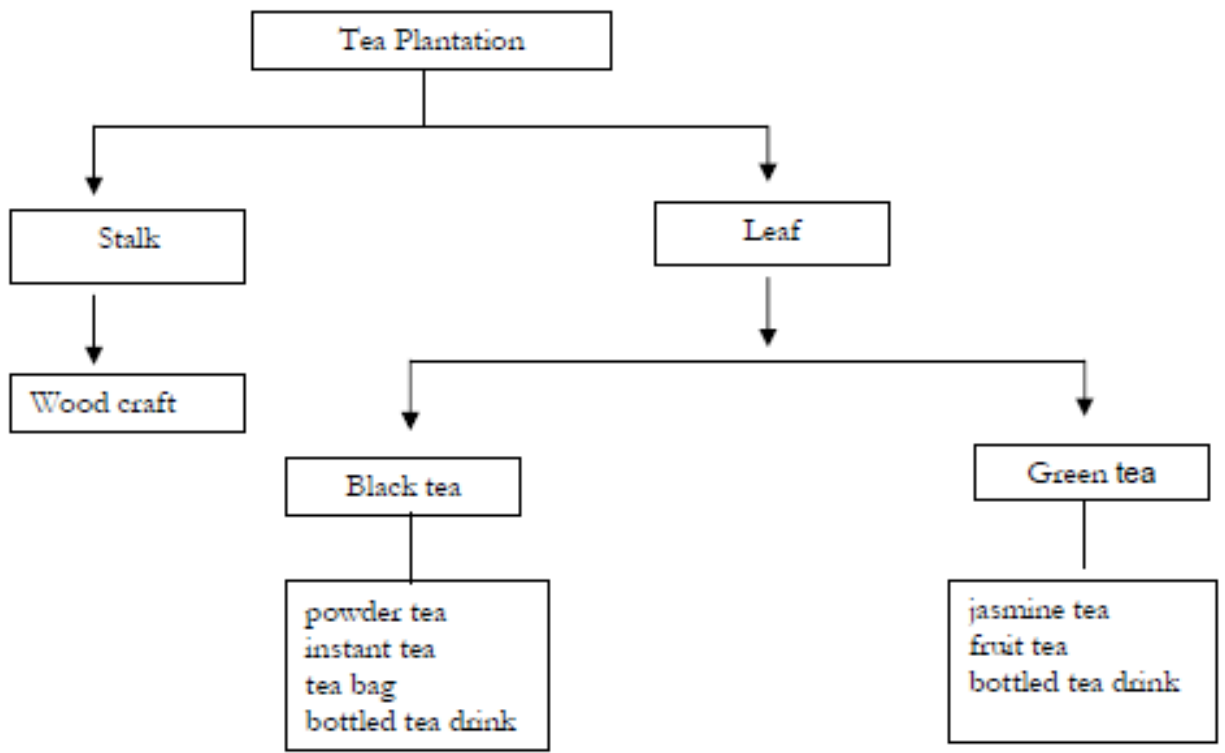

Gambar 1. Industri Teh

Sumber: (Kustanti, V. K. \&Widiyanti, T., 2007) 
Setelah daun teh dikumpulkan kemudian di keringkan dan akan mengalami proses oksidasi. Berdasarkan proses oksidasi, daun teh di kelompokkan menjadi teh putih, teh hijau, oolong, teh hitam atau teh merah, teh kuning, kukicha, genmaicha, danteh wangi.

Teh hijau adalah tipe teh yang setelah di panen harus cepat di awetkan. Sedangkan daun teh hitam di perbolehkan langsung di oksidasi setelah di panen. Daun teh hijau harus segera di panaskan untuk mencegah oksidasi. Banyak orang mengatakan bahwa rasa teh hijau pahit dan berwarna kehijauan, tetapi teh hijau memiliki banyak manfaat dalam kesehatan seperti: menjaga level kolesterol, mencegah kanker, mencegah stroke, mengurangi resiko serangan jantung, pelangsing tubuh, memperkuat kekuatan otak dan lain-lain.

\section{LATAR BELAKANG}

Mengetahui banyak keuntungan dari teh hijau dan karakteristik pasar Indonesia, PT. Sinar Sosro industri teh siap saji terbesar di Indonesia, memutuskan untuk membuat teh hijau menjadi salah satu produk menjanjikan dengan naman yang kita tahu yaitu "Joy Green Tea" pada 2007. Joy Green Tea sekarang di sajikan dalam 5 varian rasa, yang dinamakan Honeymint, Jasmine, Honey Lemon, Jasmine Less-Sugar, Apple Cinnamon., Joy Green Tea juga tersedia dalam berbagai macam varian ukuran, yaitu:

1. Joy Green Tea $234 \mathrm{ml}$ dalam bentuk botol gelas,

2. Joy Green Tea 300ml kemasan PET dengan rasa Jasmine dan Honey Lemon.

3. Joy Green Tea 500ml kemasan PET dengan rasa Jasmine, Honey Lemon, Honey Mint.

Tetapi, sejak memulai dengan total 200 produk, Joy Green Tea tidak memberikan hasil yang baik kepada Grup Sosro, yaitu berada di peringkat ketiga dibawh Nu Green Tea dan Freshtea Green. Data pasar menunjukkan data manajemen Sosro sampai akhir tahun 2012, Nu Green Tea tetap berada di peringkat satu dengan 55\%. Di peringkat kedua adalah Frestea Green dengan 25\%, sedangkan Joy Green Tea harus puas di posisi ketiga dengan 15\%. Data ini menunjukkan bahwa adanya masalah pada strategi merketing Joy Green Tea. Bagian selanjutnya akan menunjukkan masalah dan identifikasi padaPT. Sinar Sosro. 


\section{IDENTIFIKASI MASALAH}

\section{Konsumsi Teh}

Indonesia terkenal menjadi pengkonsumsi teh terendah didunia, dengan data pertahun 0.31 $\mathrm{kg}$. Orang Indonesia mengkonsumsi teh di rumah (90.5\%) dan diluar (hotel, restoran, dan semacamnya). Berdasarkan pertumbuhan pertahun, mengkonsumsi teh tidak berdampak secara signifikan terhadap penjualan teh lokal. Kurangnya pengetahuan tentang banyaknya keuntungan mengkonsumsi teh menjadi alasan utama kurang nya konsumsi teh di Indonesia. Ini merupakan data potensi pasar terhadap produk teh.

\section{Pertumbuhan konsumsi teh di Indonesia pada 1999 - 2003}

\begin{tabular}{|c|c|c|}
\hline Tahun & Konsumsi (Tons) & Pertumbuhan (\%) \\
\hline 1999 & 62,905 & - \\
\hline 2000 & 59,211 & $(5.9)$ \\
\hline 2001 & 66,299 & 11.9 \\
\hline 2002 & 68,015 & 2.6 \\
\hline 2003 & 69,647 & 2.4 \\
\hline
\end{tabular}

Sumber: www.bisnis.com

Indutri teh botol bersaing dengan air mineral botol dan industri soft drink, yaitu 30\% dari pangsa pasar. Air mineral, soft drink bersoda dan produk lain seperti jus, mengambil 40\%, $20 \%$, dan $10 \%$ dari pangsa pasar.

\section{Masalah Pokok}

Jika kita dilihat dari pertumbuhan kekuatan membeli konsumen yaitu bertambah dari $6 \%$ menjadi $8 \%$, kebiasaan konsumen, dan juga keuntungan dari teh hijau, diramalkan Joy Green Tea akan memiliki masa depan yang baik. Tetapi, dibalik kemungkinan tersebut, mengatur bagaimana produk tersebut merupakan salah satu tantangan yang besar. Selanjutnya, masalah sesungguhnya yang akan dihadapi Joy Green Tea adalah kesulitan untuk bangkit dan unggul dari para pesaing.Kami menduga ada dua masalah utama dibalik semua ini, pangsa pasar rendah dankuantitas penjualan rendahyang berdampak pada popularitas Joy Green Tea di mata konsumen Indonesia.Pada penjelasan berikut ini, kami mencoba menyajikan akar dari masalah yang mengakibatkan Joy Green Tea sulit untuk bersaing. 


\section{Keterlambatan dalam peluncuran produk}

Masalah pertama datang ketika Joy Green Tea terlambat dan kehilangkan kesempatan untuk menunjukkan produk baru mereka dari Nu Green Tea dan Freshtea Green, yang mana menyebabkan $\mathrm{Nu}$ Green Tea menjadi pemimpin pasar monopoli ini. Sangat penting untuk menjadi yang pertama dalam pasar dengan berbagai produk inovatif.Lebih cepat mendapatkan pasar dengan berbagai servis dan produk inovatif akan mendapatkan banyak keuntungan:

1. Peningkatan penjualan dan masa waktu penjualan - produk lebih cepat mencapai pasar, tergantung dari pesaing, masa waktu dapat menjadi lebih lama.

2. Peningkatan loyalitas produk - mendapat kesempatan pertama untuk menarik konsumen, memberikan penawaran menarik pada loyalitas konsumen.

Seperti yang dilakukan Teh Botol Sosro, mereka membuat merk yang tertanam di pikiran yang mengatakan “Apapun makanannya, minumnya teh botol Sosro”.Tetapi mindset ini tidak berhasil pada Joy Green Tea. Selain itu, hampir semua varian teh tidak memiliki perbedaan yang signifikan, seperti rasa, produk lain juga memiliki rasa Jasmine, Honey dan Honeymint. Melihat dari 2 fakta ini, semua industry teh hijau akan mengikuti pemimpin pasar mereka yaitu dalam hal ini Nu Green Tea.

Sebuah bentuk pasar oligopoli pada suatu pasar atau industri di dominasi oleh sedikit penjual (oligopolists). Pasar Oligopoli menghasilkan kelompok-kelompok yang mengurangi dan memimpin kompetisi dan meningkatkan harga pada konsumen. Kemungkinan lain, pasar oligopoli dapat melihat persaingan sengit jika ada pesaing yang mendapat pendapatan yang besar dan kehilangan pendapatan mereka. Dalam oligopoli tersebut, hasil bagi konsumen sering dapat menguntungkan. Dengan beberapa penjual, masing-masing perusahaan oligopoli mungkin menyadari satu sama lain dan memiliki pengaruh untuk mengikuti satu sama lain.

\section{Kurang Tepat Pada Segmentasi Produk}

Masalah pertama dapat membuat munculnya masalah berikutnya. Ketika Nu Green Tea di luncurkan ke masyarkat, perusahaan mereka telah menetapkan target pembeli yaitu pelajar sekolah, mahasiswa sampai pekerja. Yang mana Joy Green Tea mencoba mengikuti 
mereka dan membuat mereka kedalam pasar monopoli dan secara otomatis menyingkirkan pesaing mereka.

Rasa dari teh hijau masih belum sesuai dengan lidah orang Indonesia. Masih membutuhkan mindset untuk mengubah kebiasaan mereka. Kenyataannya, berdasarkan penelitian kecil, Jakarta contohnya, konsumen teh dari pelajar sampai pekerja lebih menyukai teh biasa sebagai minuman mereka. Karena rasa nya tidak pahit dan berbau seperti rasa teh hijau. Banyak dari mereka lebih menyukai mencampur teh biasa dengan gula. Tetapi, ketika teh hijau dicampur dengan gulan, rasa mereka akan menjadi aneh dan tidak enak seperti the biasa lainnya.

\subsubsection{Promosi dan Pengiklanan yang buruk}

Akar masalah lain datang dari pengiklanan produk. Kita dapat melihat metode pengiklanan tidak efisien dan juga tidak dapat meyakinkan masyarakat. Dari iklan TV tidak inovatif, selalu menggunakan tema yang sama seperti "anda haus, minum Joy Green Tea, lalu segar kembali”, sedangkan pesaing yaitu $\mathrm{Nu}$ Green Tea menggunakan tema unik pada iklan TV mereka, jadi para penonton juga tidak bosan. Berdasarkan penelitian kecil kami, hanya beberapa orang yang menyadari iklan Joy Green Tea. Itu membuktikan bahwa tidak ada pencitraan yang dibentuk pada pemikiran masyarakat.

\section{Distribusi Lemah dan Design Produk Tidak Menarik}

Terakhir, lemahnya distribusi dan design botol tidak menarik. Jika kita mencoba melihat produk teh hijau di minimarket, sangat jarang menemukan Joy Green Tea. Jikalau ditemukan, kita tidak tertarik dalam membeli karena design botol dan warna nya tidak menarik seperti yang dilakukan $N u$ Green Tea ataupun Freshtea Green. Berdasarkan penelitian kecil kami, karena samanya jenis produk, selain faktor harga, orang-orang lebih memilih produk yang sejenis berdasarkan design atau kualitas dan design dari produk.

\section{ANALISIS}

\section{Saran Untuk Kesuksesan Perubahan Produk Pada Joy Green Tea}

Kesulitan pada Sinar Sosro adalah hasil dari banyak masalah yang ditemukan sebelumnya. Kesalahan dapat diperbaiki dengan empat rekomendasi. Pertama, Sinar Sosro harus 
menyadari kesalahan strategi mereka dan mencoba membuat stategi baru. Kedua, Sinar Sosro harus mencoba membuat inovasi sehubungan dengan produk Joy Green Tea. Ketiga, Sinar Sosro harus mencoba merubah lini distribusi mereka. Keempat, Sinar Sosro harus membuat iklan yang efisien dan menarik.

\section{Mempertimbangkan kembali strategi dan membuat strategi baru.}

Dari pembahasan diatas, kita telah mengetahui bahwa hampir semua produk teh hijau tidak memiliki perbedaan dan $\mathrm{Nu}$ Green Tea adalah pemimpim pasar dari pasar oligopoli ini. Oleh karena itu, Joy Green Tea harus berhenti untuk mengikuti dan mencoba melihat segmentasi baru dimana Nu Green Tea dan Freshtea Green belum melakukannya. Dengan ini, Joy Green Tea dapat menjadi pemimpin pasar pada segmentasi yang baru. Sinar Sosro juga harus merubah pandangan mereka pada Joy Green Tea. Sinar Sosro harus membuat Joy Green Tea sama pentingnya seperti Teh Botol Sosro. Jika sudah dilakukan semua, Joy Green Tea dapat berhadapan secara langsung dengan $\mathrm{Nu}$ Green Tea.

\section{Siapa yang harus ditargetkan menjadi segmentasi yang baru?}

Segmen yang baru dimana Joy Green Tea dapat mencoba untuk masuk adalah orang-orang yang mencari gaya hidup dan orang-orang kelas menengah ke atas. Segmen ini masih bertumbuh dan banyak literatur yang akan meningkat pada dekade selanjutnya. Itulah mengapa, ini lebih baik daripada masuk pada segmentasi pasar pesaing, dan dapat menggunakan pencitraan baru dan mencocokan dengan selera mereka terhadap rasa dan design produk.

\section{Mengapa harus menargetkan pencari gaya hidup dan orang kelas menengah keatas?}

Perkembangan ekonomi orang Indonesia menengah keatas sangat signifikan. Orang-orang ini cenderung mengkonsumsi dan mencari gaya hidup baru dibanding harga. Menteri ekonomi Ir. M. Hatta Radjasa mengatakan pada 2003, total orang menengah ke atas sekitar 81 juta. Lalu pada 2010 total kelas tersebut mencapai 131 juta. Dan juga, jika kita melihat pada kebiasaan konsumen, kita dapat tahu banyak dari mereka mempunyai kebiasaan mengkonsumi lebih dari yang mereka dapatkan. Segmentasi ini bergerak dari setiap tahun, termasuk: pelajar, pekerja, dan juga orang lanjut usia. Bahkan, pelajar dewasa ini memperhatikan gaya hidup mereka. 


\section{Bagaimana cara untuk masuk ke segmentasi orang pencari gaya hidup dan orang menengah keatas?}

Ada banyak cara untuk melakukan ini. Pertama mereka harus membuat inovasi baru untuk segmen yang baru. Membuat invoasi baru pada tampilan produk adalah hal baik yang dapat dilakukan. Di Indonesia, konsumen lebih menyukai tampilan menarik daripada penggunaanya. Pada orang-orang kelas atas, tampilan adalah yang paling penting. Jika kita dapat membuat design yang menarik dan dapat membuat mereka berfikir bawha ini merupakan teh yang elit atau special, mereka akan menerima produk tersebut dan membelinya..

\section{Inovasi apa yang harus kita buat?}

Inovasi adalah salah satu dari hal yang sangat penting yang harus dilakukan jika industry ingin menjadi lebih baik di pasar. Inovasi dapat termasuk banyak hal seperti: kemasan, rasa, promosi baru, dan lain lain. Tim kami memulai untuk melakukan survey mengenai rasa setiap produk dan mengetahui rasa Joy Green Tea lebih terasa rasa daun teh hijau nya disbanding produk lain. Jadi disimpulkan bahwa orang Indonesia tidak menyukai rasa yang terlalu pekat seperti itu dan hal yang harus mereka perbaiki adalah membuat spesifikasi yang baik dan benar untuk segmen yang baru nanti. Dari kalimat diatas, kita telah mengetahui bahwa orang Indonesia lebih menyukai yang berhubungan dengan gaya hidup. Joy Green Tea harus memilih untuk membuat merk spesifik yang baru seperti Chinese Green Tea karena memberi rasa herbal yang lebih disukai tetapi juga memberikan rasa yang lebih menyegarkan. Selain itu dengan kata"Chinese", banyak orang akan memiliki pandangan yang baru terhadap rasa dari Chinese Green Tea. Dan, dengan rasa baru ini, Joy Green Tea akan menetapkan orang-orang tua atau lanjut usia yang menyukai meminum Chinese Green Tea.

Kami mencoba untuk mengadakan eksperimen kecil dengan 30 responden secara acak. Mereka ditanya untuk memilih mana yang mereka lebih sukai dari 3 sampel produk teh hijau; Joy Green Tea, Nu Green Tea, dan Frestea Green dengan rasa yang sama yaitu rasa madu. Hasilnya $\mathrm{Nu}$ Green Tea menjadi yang lebih disukai dibanding 3 produk lainnya. Hasilnya ditampilkan sebagai berikut. 


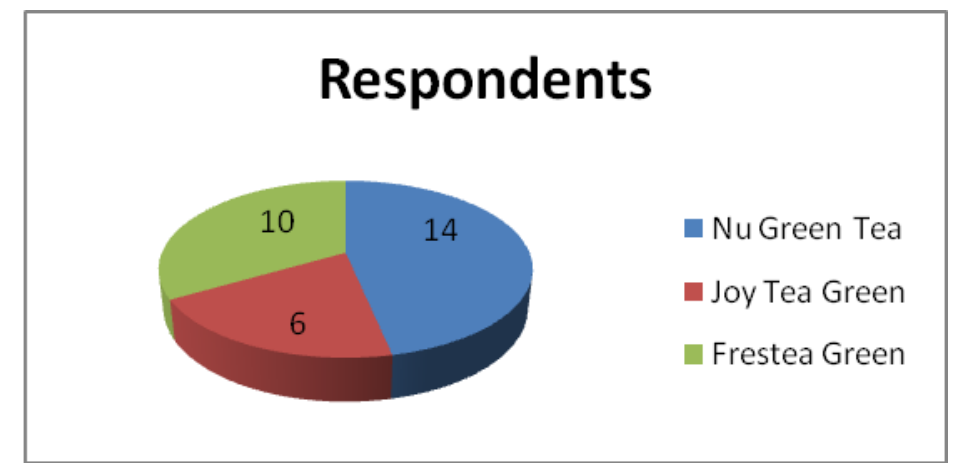

\section{Pilihan Responden Dari Minuman Teh Hijau}

Memperbaiki lini distribusi. Lini distribusi dari Joy Green Tea dapat menjadi masalah. Tim kami telah mensurvei beberapa minimarket atau pedagang di Jakarta. Yang kami temukan adalah hampir semua pedagang tidak menjual produk Joy Green Tea. Nu Green Tea merupakan yang paling mudah ditemukan di setiap pasar. Jadi, sarannya adalah Sinar Sosro harus mencoba bekerja sama dengan banyak pedagang untuk melakukan promosi produk, untuk terus bertahan dipasar dan membuat produk tetap ada.

Membuat iklan menjadi lebih menarik dan efisien. Sampai sekarang, Sinar Sosro hanya mencoba untuk membuat iklan dengan tema yang sama yaitu "haus? minum Joy Green Tea, lalu segar kembali”. Ini harus mengalami perubahan. Iklan yang tidak menarik tidak akan menarik konsumen dan hanya membuang-buang uang. Kami menyarankan Sinar Sosro harus membuat tema yang berbeda yang menarik pelanggan. Iklan yang menarik juga harus memilih tempat yang menarik juga. Menggunakan aktor juga merupakan ide yang baik, itu dapat membuat penonton mengingat bahwa aktor favorit mereka meminum Joy Green Tea. Dimana iklan harus di tempatkan? Kita dapat menempatkan iklan di kereta, karena banyak penumpang kereta dapat melihat dan membeli produk tersebut. Kapan kita harus menempatkan iklan TV? Joy Green Tea harus mengetahui kapan orang-orang beristirahat dan menonton TV. Mungkin di waktu siaran sinetron atau mungkin saat siaran olah raga merupakan tempat yang bagus.

Membuat program berhubungan dengan tanggung jawab sosial perusahaan. Melihat fakta bahwa lifebuoy sukses menempatkan strategi yang baik. Jika Joy Green Tea dapat melakukannya juga, nama mereka akan terangkat di mata publik. Dengan nama yang sudah 
terkenal di kalangan konsumen, setiap minimarket dan pedagang akan menjual produk Joy Green Tea kepada konsumen. Itu akan menjadi solusi yang baik untuk menarik pelanggan.

Menyarankan rancangan botol baru (yang bersahabat dengan lingkungan) Kami menyarakankan rancangan botol premium yang baru dan dapat membawa inovasi baru untuk Joy Green Tea, agar volume penjualan dapat meningkat. Kami percaya bahwa inovasi baru ini dapat memberikan gagasan kepada pelanggan terhhadap produk Joy Green $T e a$. Rancangan botol baru ini memiliki sifat bersahabat dengan lingkungan dan rancangan yang cocok dengan genggaman tangan untuk memudahkan konsumen untuk meminum produk. Lalu, tutupan botol dengan model yang dapat dikunci, jadi memudahkan untuk dibawa dan tidak mudah tumpah. Rancangan botol baru dapat dilihat di lampiran laporan ini. Label dari botol bebas untuk di rancang ulang, yang ingin kami tunjukkan hanya rancangan botolnya saja.

Botol produk terbuat dari bahan daur ulang, yaitu tapioka dicampur dengan plastik sintetis dan zat aditif sesuai porsi nya masing-masing. Hasilnya, plastik komposit dengan sifat dan karakter yang sama dengan plastik sintetis, tetapi dapat terurai dan tidak berbahaya dengan metode termoplastik. Kerugiannya adalah bahannya sulit ditemukan dan tidak selalu ada dan disamping masih ada bahan selain komposisi plastik dan tidak terurai sempurna.

\section{RINGKASAN}

Kita telah memasuki era inovasi. Hal ini memperluas dan mempengaruhi cara perusahaan berpikir pada hampir setiap aspek penelitian, pemasaran pengembangan produk, manajemen pemasok dan bahan, manufaktur, distribusi, garansi, dan lain.Satu dari kesempatan terbaik untuk meningkatkan keuntungan melalui produk baru, servis, pasar baru dan hubungan baik dengan pelanggan. Menurut studi CEO, produk/layanan/pasar inovator mempertahankan 1,2 persen operasi margin yang lebih tinggi daripada kompetitor mereka. Menggunakan saluran elektronik untuk meningkatkan jangkauan dan menembus pasar baru.

Ironisnya, perusahaan semakin bergantung pada pertumbuhan produk baru dan layanan untuk memenuhi target pertumbuhan baru, produk dengan inovasi baru memiliki tingkat keberhasilan yang sangat rendah, kita harus hati-hati mengambil tindakan ini. Salah satu 
alasan utama untuk kegagalan peluncuran produk adalah gagal dan dengan buruk menentukan kebutuhan pelanggan. Lainnya adalah kurangnya strategi bisnis yang jelas terkait dengan tujuan rantai pasokan dan inisiatif untuk produk yang akan diluncurkan ke pasar dan layanan pelanggan. tidak cukup sumber daya manusia dan uang serta kurangnya dukungan eksekutif adalah alasan lain untuk kegagalan peluncuran produk. Kita meringkas beberapa yang tidak dapat dilihat belum oleh PT. Sinar Sosro:

1. Inovasi bukan hanya tanggung jawab manajer produk, inovasi harus ditentukan dari atas.

2. Banyak yang mengatakan bahwa inovasi biasanya berasal dari tim riset dan pengembangan, tetapi kita melihat kerja sama dari pihak luar dirasa tidak diperlukan.

3. Inovasi tidak hanya berarti produk yang baru atau servis yang lebih baik, tetapi, kita berpendapat model bisnis dan inovasi operasi juga sangat penting.

\section{KESIMPULAN DAN SARAN}

Analisis laporan ini menghasilkan beberapa kesimpulan:

1. Kurangnya pangsa pasar dan volume penjualan produk Joy Green Tea mengakibatkan berkurangnya pendapatan.

2. Kami menyimpulkan dari beberapa masalah Joy Green Tea yang mengakibatkan rendahnya volume penjualan, pertama adalah komitmen dari manajemen puncak untuk memperhatikan lebih Joy Green Tea seperti atau lebih dar Teh Botol Sosro; Keterlambatan dalam peluncuran produk; segmentasi produk yang kuran tepat; buruknya promosi dan iklan; dan yang terakhir lemahnya distribusi.

3. Joy Green Tea membutuhkan inovasi baru di segala sektor, dari produk, servis, supplier, manajemen material, manufaktur, dan distribusi dengan promosi yang membuat volume dan pangsa pasar meningkat.

4. Joy Green Tea harus merubah strategi bisnis mereka menjadi berbeda dari pesaing yang sudah lebih dahulu meluncurkan produk. 
Analisis laporan juga memberikan saran:

1. Joy Green Tea tidak harus mengikuti strategi $\mathrm{Nu}$ Green Tea yang membuat berbagai varian rasa. Mereka harus datang dengan inovasi baru yang belum ada sebelumnya tetapi, intinya rasa yang ada harus sesuai dengan keinginan pelanggan. Kami menyarankan teh hijau yang dikombinasikan dengan susu dapat menjadi alternative, dengan menganggap susu di konsumsi segala usia.

2. Joy Green Tea harus membedakan produk mereka dan menggunakan produk yang belum pernah masuk ke pasar oleh industry lain dalam hal ini segmentasi kelas atas jika mereka ingin mempertahan kan rasa teh hijau mereka.

3. Joy Green Tea dapat mempromosikan produk mereka melalui kegiatan sosial di kolaborasi dengan sifat perusahaan, contohnya dengan menjadi perusahaan yang menyajikan minuman kesehatan pada suatu kegiatan sosial pada acara kesehatan.

4. Joy Green Tea harus memberikan tema pada produk mereka seperti teh botol sosro “apapun makanannya, minumnya teh botol sosro".Yang dapat membuat orangorang mengingat produk mereka.

5. Joy Green Tea dapat mempromosukan produk mereka dengan iklan yang efektif. Kita dapat menempatkan iklan pada kereta, karena banyak orang di kereta dapat melihat dan membeli produk tersebut.

6. Joy Green Tea harus menyelesaikan lini distribusi mereka dengan menambahkan agen atau sub agen untuk mempertahan kan produk mereka tetap ada pada di gerai rittel terbawah.

7. Joy Green Tea dapat menjadi yang pertama mencanangkan program perusahaan dengan tanggung jawab sosila pada sektor teh.

\section{LAMPIRAN}

Dibagian lampiran ini menjelaskan rancangan baru dari botol Joy Green Tea dengan konsep lingkungan hijau atau ramah lingkungan. Ini merupakan botol sekali pakai karena botol menyusut $60 \%$ setelah penggunaan. 


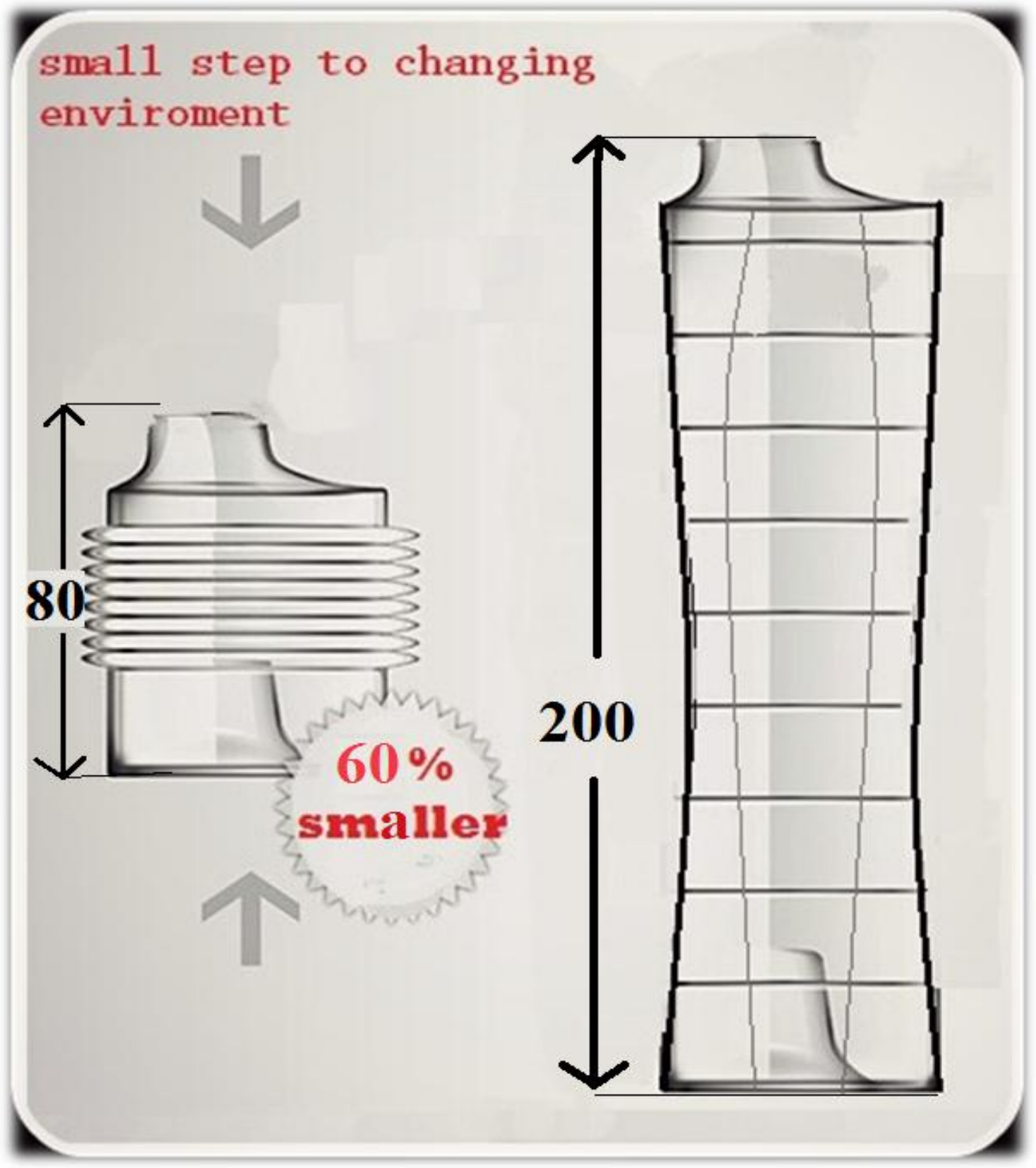

Rancangan Botol Baru Menyusut (Sampai 60\%) Setelah Penggunaan 


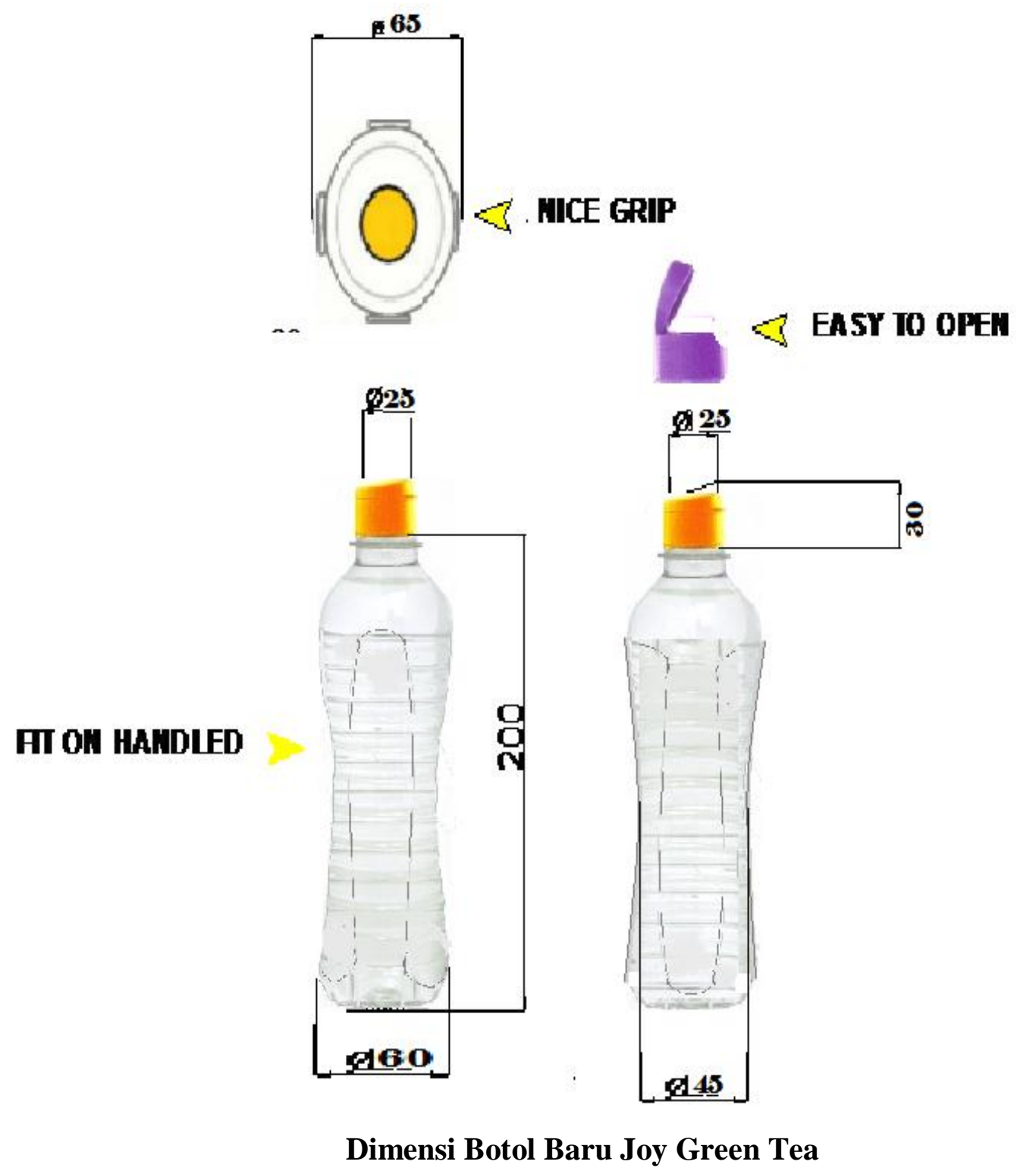

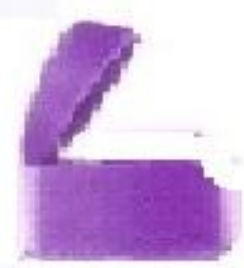

BEFORE

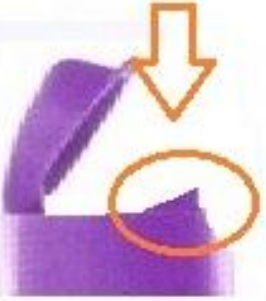

AFTER

. Inovasi Dari Leher Botol 
Ini dilakukan untuk memberikan pelanggan kenyamanan saat meminum nya, air atau dalam hal ini the akan lebih terkontrol saat sampai ke mulut(tidak tumpah) karena mengikuti bentuk dari tutup botol.

\section{Interface}

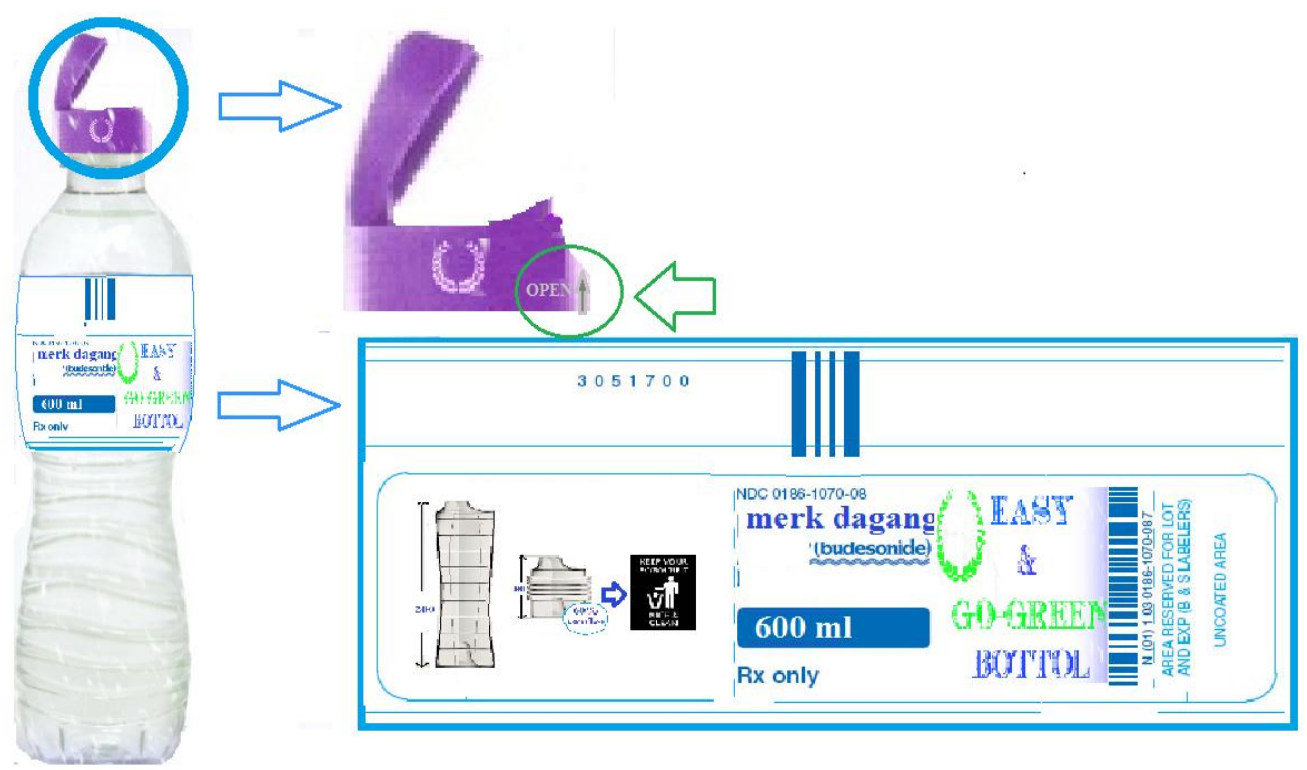

\section{Tampilan dari Botol Baru Joy Green Tea}

Di bagian depan, ada instruksi cara membuka tutup botol, jadi pelanggan akan mengetahui langsung cara membuka botol.

Pada labelnya ditunjukkan proses yang harus dilakukan setelah habis menggunakannya sebelum dibuang ke tempat sampah. Ini juga merupakan satu langkah perusahaan peduli pada lingkungan dengan menyarankan rancangan botol yang dapat terurai. Label ini bebas untuk di rancang ulang, karena inti dari ini adalah untuk menjual rancangan botol yang ramah lingkungan. 


\section{Produk Jadi}

Dibawah ini adalah produk jadi botol baru Joy Green Tea

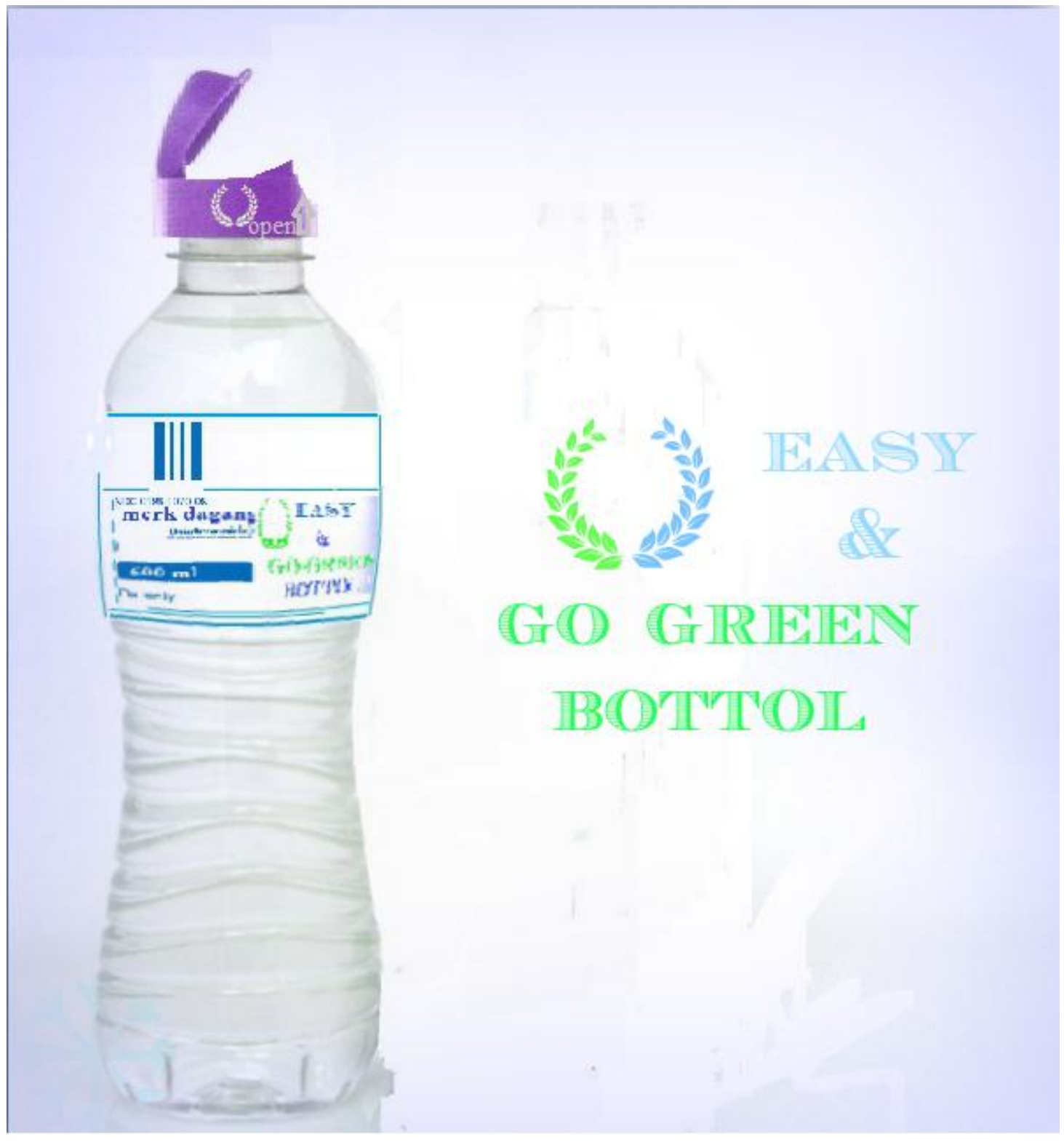

Tampilan Produk Jadi dari Joy Green Tea 


\section{DAFTAR PUSTAKA}

http://www.sosro.com/sejarah-teh-indonesia.php, Terakhir Diakses Tanggal 22 April 2013.

Kustanti, V, R,.\&Widiyanti, T,. "Research on Supply Chain in The Tea Sector in Indonesia”. The Business Watch Indonesia. 2007.

http://2tang.net/en/type-of-tea/, Terakhir Diakses Tanggal 22 April 2013.

Suprihartini, R,."Studi Banding PemasaranTeh India dan Indonesia”.INFO THE. $6^{\text {th }}$ edition, 1999. P. 18-22.

Expanding the Innovation Horizon: The Global CEO Study 2006." IBM Corporation. March 2006. http://www.ibm.com/bcs/ceostudy. 